\title{
FERMENTATION, LOSSES, AND AEROBIC STABILITY OF SUGARCANE SILAGES TREATED WITH CHEMICAL OR BACTERIAL ADDITIVES
}

André de Faria Pedroso ${ }^{1 *}$; Luiz Gustavo Nussio²; Daniele Rebouças Santana Loures ${ }^{3}$; Solidete de Fátima Paziani ${ }^{4}$; José Leonardo Ribeiro²; Lucas José Mari²; Maity Zopollatto²; Patrick Schmidt ${ }^{5}$ Wilson Roberto Soares Mattos ${ }^{2}$;orge Horii ${ }^{6}$

${ }^{1}$ Embrapa Pecuária Sudeste, C.P. 339 - 13560-970 - São Carlos, SP - Brasil.

${ }^{2}$ USP/ESALQ - Depto. de Zootecnia, C.P. 09 - 13418-900 - Piracicaba, SP - Brasil.

${ }^{3}$ UESC - Depto. de Ciências Agrárias e Ambientais, Rod. Ilhéus/Itabuna, km 16 - 45662-000 - Ilhéus, BA - Brasil.

${ }_{5}^{4}$ Rua Alagoas 944, apto. 22 - 15801-310 - Catanduva, SP - Brasil.

${ }^{5}$ UNESP - Rua Tamekishi Takano, 5 - 11900-000 - Registro, SP - Brasil.

${ }^{6}$ USP/ESALQ - Depto. de Agroindústria, Alimentos e Nutrição, C.P. 09 - 13418-900 - Piracicaba, SP - Brasil.

*Corresponding author <andref@cppse.embrapa.br>

ABSTRACT: Utilization of sugarcane Saccharum officinarum L. silage is increasing in Brazil but intensive ethanol production during fermentation reduces forage quality. This experiment aimed to evaluate the effects of additives on fermentation and aerobic stability of sugarcane silages produced in minisilos. Treatments were (fresh basis): untreated silage (control), urea $\left(5.0 \mathrm{~g} \mathrm{~kg}^{-1}\right)$, sodium benzoate $\left(1.0 \mathrm{~g} \mathrm{~kg}^{-1}\right)$, potassium sorbate $\left(0.3 \mathrm{~g} \mathrm{~kg}^{-1}\right)$, Lactobacillus plantarum $\left(1 \times 10^{6} \mathrm{cfu} \mathrm{g}^{-1}\right)$, and Lactobacillus buchneri $\left(3.64 \times 10^{5} \mathrm{cfu}^{-1}\right)$. At the 94th day after ensilage, ethanol concentration was lower in urea, benzoate, sorbate and $L$. buchneri supplemented silages and higher in L. plantarum inoculated silage, as compared to control. Urea and benzoate treated silages showed the highest and L. plantarum treated silage the lowest in vitro dry matter digestibility. Effluent production was higher in the urea treated silage. Inoculation with L. buchneri reduced $50 \%$ ethanol production as compared to control. Urea and L. buchneri reduced yeast count. Aerobic stability was enhanced by L. buchneri and benzoate. Sodium benzoate and $L$. buchneri were the most promising additives, improving both silage fermentation and aerobic stability; inoculants containing $L$. plantarum can be deleterious to fermentation and conservation of sugarcane silages.

Key words: Lactobacillus buchneri, Lactobacillus plantarum, ethanol, benzoate, sorbate

\section{FERMENTAÇÃO, PERDAS E ESTABILIDADE AERÓBIA DE SILAGENS DE CANA-DE-AÇÚCAR TRATADAS COM ADITIVOS QUÍMICOS OU BACTERIANOS}

RESUMO: A utilização de silagem de cana-de-açúcar (Saccharum officinarum L.) está aumentando no Brasil, mas a intensa produção de etanol durante a fermentação reduz a qualidade da forragem. Este experimento visou avaliar os efeitos de aditivos na fermentação e estabilidade aeróbia de silagens de cana-de-açúcar produzidas em minisilos. Os tratamentos foram (base matéria verde): silagem sem tratamento (controle), uréia $\left(5,0 \mathrm{~g} \mathrm{~kg}^{-1}\right)$, benzoato de sódio $\left(1,0 \mathrm{~g} \mathrm{~kg}^{-1}\right)$, sorbato de potássio $\left(0,3 \mathrm{~g} \mathrm{~kg}^{-1}\right)$, Lactobacillus plantarum $\left(1 \times 10^{6} \mathrm{ufc}^{-1}\right)$ e Lactobacillus buchneri $\left(3,64 \times 10^{5}\right.$ ufc $\left.\mathrm{g}^{-1}\right)$. Aos 94 dias após a ensilagem, a concentração de etanol foi mais baixa nos tratamentos uréia, benzoato, sorbato e L. buchneri e mais alta para L. plantarum, em relação ao controle. As silagens dos tratamentos com uréia e benzoato tiveram as mais altas, e o tratamento com L. plantarum a mais baixa digestibilidade in vitro da matéria seca. A produção de efluentes foi mais alta no tratamento com uréia. A inoculação com L. buchneri reduziu em 50\% o etanol na silagem em relação ao controle. Uréia e L. buchneri reduziram a contagem de leveduras. L. buchneri e benzoato aumentaram a estabilidade aeróbia. O benzoato de sódio e L. buchneri foram os aditivos mais promissores, melhorando a fermentação e a estabilidade aeróbia nas silagens; inoculantes contendo L. plantarum podem ser prejudiciais à fermentação e conservação de silagens de canade-açúcar.

Palavras-chave: Lactobacillus buchneri, Lactobacillus plantarum, etanol, benzoato, sorbato 


\section{INTRODUCTION}

Sugarcane (Saccharum officinarum L.) is broadly used for feeding cattle in Brazil during winter. When corrected for protein and minerals it can support moderate animal performance (Boin \& Tedeschi, 1993). Traditionally sugarcane is harvested daily and fed green-chopped; sucarcane preserved as silage can be fed all year around but high alcohol production is a major contributor to dry matter losses - DML. (Alli et al., 1982; Pedroso et al., 2005; Junqueira, 2006).

Several additives have been evaluated in order to reduce yeast population during ensiling of sugarcane. Siqueira (2005) and Junqueira (2006) showed a reduction in ethanol production and DML in urea treated silage. Siqueira (2005) observed greater DM recovery and higher digestibility in sodium benzoate treated silage. Inoculation with Lactobacillus buchneri reduced ethanol production and improved silage DM recovery (Siqueira, 2005; Junqueira, 2006). In addition, urea and L. buchneri also improved somewhat the aerobic (Siqueira, 2005; Junqueira, 2006).

Inoculants containing lactic acid homofermentative bacteria have been increasingly recommended in Brazil as additives for sugarcane ensiling. However, $\mathrm{pH}$ reduction per se does not inhibit yeast development and, in addition, lactic acid has a limited fungicidal action (McDonald et al., 1991), evidences that encourage studies to evaluate the efficacy of these additives to reduce alcohol production in sugarcane silage.

The objective of this experiment was to evaluate the effect of chemical and bacterial additives on ethanol production, fermentation, DML and aerobic stability of sugarcane silage

\section{MATERIAL AND METHODS}

Silages were produced with sugarcane, variety RB785841, approximately 12 months old (second cut; $17.5^{\circ}$ Brix) mechanically harvested adjusted for a theoretical cut length between 5 and $10 \mathrm{~mm}$. Approximately $9 \mathrm{~kg}$ of the chopped forage were packed into $20 \mathrm{~L}$ plastic buckets (minisilos), sealed with tight lids containing Bunsen type valves. Each minisilo was provided with an apparatus for effluent quantification, consisting of $2 \mathrm{~kg}$ of dry sand separated from the chopped forage by a thin plastic screen and two layers of cheesecloth. Additives were added to the chopped sugarcane before ensiling, using aqueous solutions applied with manual sprayers. The following treatments were applied to the fresh forage: 1) untreated (Control), 2) urea, $5 \mathrm{~g} \mathrm{~kg}^{-1}$ of fresh forage (UREA), 3) sodium benzoate, $1 \mathrm{~g} \mathrm{k}^{-1}$ of fresh forage
(BENZ), 4) potassium sorbate, $0.3 \mathrm{~g} \mathrm{k}^{-1}$ of fresh forage (SORB), 5) L. plantarum (ECOSYL ${ }^{\circledR}$, ECOSYL Products Limited), $1 \times 10^{6} \mathrm{cfu} \mathrm{g}^{-1}$ of fresh forage (LAB), and 6) L. buchneri (strain NCIMB $40788^{\circledR}$, Biotal Ltd, Cardiff, UK), $3.64 \times 10^{5} \mathrm{cfu} \mathrm{g}^{-1}$ of fresh forage (BUCH). The bacterial inoculants, UREA, BENZ and SORB solutions were applied at the rate of 1.89 $\mathrm{L} \mathrm{t}^{-1}, 30 \mathrm{~L} \mathrm{t}^{-1}, 12 \mathrm{~L} \mathrm{t}^{-1}$ and $12 \mathrm{~L} \mathrm{t}^{-1}$ of forage, respectively.

The minisilos were weighed and sampled on day 0 and 94 days after ensiling. Effluent was estimated by weight gain of the minisilos containing only the apparatus for effluent collection. Dry matter loss was calculated by DM weight loss. Samples to be analysed for water soluble carbohydrates (WSC), crude protein $(\mathrm{CP})$, ethanol and $\mathrm{pH}$ determinations were frozen $\left(-10^{\circ} \mathrm{C}\right)$ before analysis. Samples to be analysed for yeast count (approximately $25 \mathrm{~g}$ ) were placed in plastic bags and kept on ice 24 hours maximum before analytical procedure was done according to Kurtman and Fell (1998). Other samples were dried in a forced air dry oven $\left(60^{\circ} \mathrm{C}, 48 \mathrm{~h}\right)$ and grounded in a Wiley mill through a $1 \mathrm{~mm}$ screen. Dry chemistry analysis was performed by Near Infrared Spectroscopy (NIRS) (Berzaghi et al., 1997) in a spectrophotometer model NIRS $5000^{\circledR}$ (NIRSystems, Silver Spring, USA). The equipment software indicated that approximately $30 \%$ of the samples had to be analyzed by wet chemistry for subsequent inference of the composition of all samples. Wet chemical analysis followed the Association of Official Analytical Chemists (1990) recommendations for DM and CP. Neutral detergent fiber (NDFom) was assayed with sodium sulfite and without alpha amylase according to Soest \& Robertson (1985) and expressed on an ash-free basis. In vitro dry matter digestibility was estimated in a Daisy incubator (ANKON Technology Corporation, Fairport, USA). Ethanol, WSC and $\mathrm{pH}$ were determined in aqueous extracts according to the method described by Kung Jr. et al. (1984). Water soluble carbohydrates were determined by the phenol sulfuric acid method (Dubois et al., 1956). Ethanol was analyzed in a Hewlett Packard 5890 Series II gas chromatograph, equipped with a flame ionization detector, a 2-m $\times 2$-mm ID column packed with chromosorb 101 (Johns- Manville, Denver, USA) and an electronic integrator. Silage $\mathrm{pH}$ was measured with a digital potentiometer.

For aerobic stability evaluation, samples of approximately $3.5 \mathrm{~kg}$ of each replicate were loosely transferred to plastic buckets kept at room temperature (22 to $28^{\circ} \mathrm{C}$; average $24.7^{\circ} \mathrm{C}$ ). Temperature was recorded twice daily (8:30 and 17:30 h) through thermometers positioned at the center of the forage mass. Aerobic 
stability was defined as the number of hours taken to silage temperature to increase more than $2^{\circ} \mathrm{C}$ above room temperature (Higginbotham et al., 1998; Kung Jr. et al., 2000). The cumulative daily medium difference (CDMD) between silage temperature and room temperature, after five (CDMD-5) and ten days (CDMD-10) of air exposure was used to evaluate aerobic deterioration intensity.

Data were analyzed as a completely randomized design and subjected to ANOVA by the GLM procedure of SAS (1988). Differences among means were tested using Duncan's test $(p<0.05)$.

\section{RESULTS AND DISCUSSION}

Dry matter, CP and WSC concentrations in fresh sugarcane were within normal levels, whereas NDF levels were higher and IVDMD were lower than reported literature levels (Table 1). The digestibility of well managed Brazilian varieties of sugarcane varies from 580 to $690 \mathrm{~g} \mathrm{~kg}^{-1}$ (Andrade et al., 2002; Rodrigues et al., 2001). Digestibility is highly influenced by fiber and sugar concentrations in the forage and the lower the ratio NDF:sugars, the higher the IVDMD (Rodrigues et al., 2001). Therefore, the high sugarcane NDF content in this experiment may have caused the lower digestibility as compared to reported values, although the WSC levels were comparable to literature values.

All silages showed final $\mathrm{pH}$ values indicative of normal fermentation. Silages with high ethanol concentration tend to show a slow decline and higher than desirable pH values. Driehuis \& Wikselaar (2000) re- ported that grass silages with 48 to $63 \mathrm{~g} \mathrm{k}^{-1}$ of ethanol DM basis, showed final $\mathrm{pH}$ above 5.3. Sugarcane usually shows high levels of ethanol and $\mathrm{pH}$ falls very fast to final values around 3.5 (Pedroso et al., 2005; Siqueira, 2005; Junqueira, 2006). Forage low buffering capacity allows a fast drop in $\mathrm{pH}$ even when acid production is small (Alli et al., 1983).

Yeast count was high in the control silage but ethanol content was unusually low as well as DML (Table 1). Ethanol concentration values ranging from approximately 58 to $140 \mathrm{~g} \mathrm{~kg}^{-1}$ have been reported for silages produced with 12 months old sugarcane with no additives (Junqueira, 2006; Bernardes et al., 2002). Pedroso et al. (2005) reported values of approximately $70 \mathrm{~g} \mathrm{~kg}^{-1}$ of ethanol (DM basis) and $300 \mathrm{~g} \mathrm{~kg}^{-1}$ of DML in untreated sugarcane silage, 90 days after ensilage. Ethanol concentrations on this study were lower than expected, despite the observed high yeast count, $40.5 \mathrm{~g} \mathrm{~kg}^{-1} \mathrm{DM}$ for control silage. Higher ethanol concentration (90 $\mathrm{g} \mathrm{kg}^{-1}$ in DM) was reported for silage with lower yeast and mould population (approximately, $3.3 \log \mathrm{cfu} \mathrm{g}^{-1}$ ) (Alli et al., 1983).

During the 94 day storage period, control silage showed high loss of WSC, increase in fiber components and reduction in IVDMD, characteristic of sugarcane silages produced without additives (Pedroso et al., 2005; Siqueira, 2005). All additives, excluding $\mathrm{LAB}$, were effective in reducing ethanol production although effects on losses and IVDMD were variable (Table 1). L. plantarum treated silage showed a large WSC loss (66\%) and the lowest $\mathrm{pH}$ among the treatements, suggesting an intensive use of sugars into lactic acid production. It did not reduce yeast count

Table 1 - Chemical composition ( $\mathrm{g} \mathrm{kg}^{-1}$ of DM, unless stated otherwise) of fresh sugarcane and parameters of losses, IVDMD and yeast counts of sugarcane silages, 94 days after ensiling with and without additives.

\begin{tabular}{|c|c|c|c|c|c|c|c|c|}
\hline \multirow{2}{*}{ Parameter $^{(2)}$} & \multicolumn{8}{|c|}{ Treatment $t^{(1)}$} \\
\hline & Fresh sugarcane & Control & Urea & BENZ & SORB & $\mathrm{BUCH}$ & LAB & SEM \\
\hline $\mathrm{DM}\left(\mathrm{g} \mathrm{kg}^{-1}\right)$ & 305 & 280 & 273 & 274 & 285 & 304 & 275 & 17 \\
\hline $\mathrm{CP}$ & 33.2 & $33.7^{b}$ & $74.2^{\mathrm{a}}$ & $29.4^{\mathrm{b}}$ & $31.6^{\mathrm{b}}$ & $30.2^{\mathrm{b}}$ & $34.3^{\mathrm{b}}$ & 3.3 \\
\hline NDFom & 551 & $595^{\mathrm{c}}$ & $560^{d}$ & $590^{c}$ & $602^{c}$ & $620^{\mathrm{b}}$ & $647^{\mathrm{a}}$ & 8 \\
\hline WSC & 233 & $91.3^{\mathrm{bc}}$ & $92.1^{\mathrm{bc}}$ & $134.0^{\mathrm{a}}$ & $106.0^{\mathrm{b}}$ & $56.9^{d}$ & $79.2^{\mathrm{cd}}$ & 13.7 \\
\hline Ethanol & nd & $40.5^{b}$ & $24.8^{\mathrm{de}}$ & $32.1^{\mathrm{c}}$ & $29.3^{\mathrm{cd}}$ & $19.0^{\mathrm{e}}$ & $49.0^{\mathrm{a}}$ & 3.8 \\
\hline IVDMD & 513 & $466^{\mathrm{bc}}$ & $486^{\mathrm{a}}$ & $478^{\mathrm{ab}}$ & $464^{\mathrm{bc}}$ & $460^{c}$ & $439^{d}$ & 7 \\
\hline $\mathrm{pH}$ & nd & $3.65^{\mathrm{c}}$ & $3.81^{\mathrm{a}}$ & $3.70^{\mathrm{b}}$ & $3.64^{\mathrm{c}}$ & $3.65^{\mathrm{c}}$ & $3.57^{\mathrm{d}}$ & 0.03 \\
\hline DML & - & $68.2^{\mathrm{cd}}$ & $126.0^{\mathrm{a}}$ & $104.3^{\mathrm{abc}}$ & $114.9^{\mathrm{ab}}$ & $51.9^{d}$ & $77.0^{\mathrm{bcd}}$ & 20.7 \\
\hline Effluent $\left(\mathrm{kg} \mathrm{t}^{-1}\right)$ & - & $6.98^{\mathrm{cd}}$ & $23.62^{\mathrm{a}}$ & $12.24^{\mathrm{b}}$ & $11.05^{\mathrm{bc}}$ & $2.30^{\mathrm{de}}$ & $0.59^{\mathrm{e}}$ & 2.71 \\
\hline Yeast $\left(\log \mathrm{cfu}^{-1}\right)$ & nd & $6.42^{\mathrm{a}}$ & $4.78^{\mathrm{bc}}$ & $5.43^{\mathrm{abc}}$ & $5.10^{\mathrm{abc}}$ & $3.92^{\mathrm{c}}$ & $5.53^{\mathrm{ab}}$ & 0.77 \\
\hline
\end{tabular}


and showed the highest ethanol production among all silages and a higher NDF and lower IVDMD as compared to the control silage. A reduced effluent production was the only positive effect of this additive. Previous results of LAB inoculated sugarcane silage indicated that this additive has a deleterious effect on the fermentation process. Pedroso (2003) also detected an increase in ethanol production leading to high silage DML and reduced IVDMD. Increasing lactic acid production in sugarcane silages doesn't seem to be an appropriate strategy to improve fermentation and its preservation, for yeasts are not inhibited by lower $\mathrm{pH}$ (McDonald et al., 1991). In addition, lactic acid has weak direct fungicidal action (Moon, 1983). Also a faster decrease in $\mathrm{pH}$ may restrict the activity of enterobacteria and other heterofermentative bacteria, which will reduce acetic acid production and will favor conditions for yeast growth.

Lactobacillus buchneri treated silage showed a loss in WSC similar to the L. plantarum treated silage, but a higher final $\mathrm{pH}$, probably due to the higher acetic acid production by the heterolactic bacteria, a weaker acid than lactic acid. Also L. buchneri treated silage showed the lowest yeast count across all silages and a 50\% reduction in ethanol production as compared to control. Effluent was low but inoculation with the heterolactic bacteria did not improve DML and silage IVDMD relative to control. The overall effect of L. bucheneri inoculation found in this study is in accordance with previous results obtained by Pedroso (2003), that is, reduction in yeast population and ethanol production and improvement in DM recovery. Junqueira (2006) reported improvement in DM recovery and reduction in ethanol content in silage inoculated with a lower concentration of these bacteria ( 5 $\left.\times 10^{4} \mathrm{ufc} \mathrm{g}^{-1}\right)$. Inoculation with $L$. buchneri promotes reduction in yeast count due to an increase in acetic acid concentration (Driehuis et al., 1999; Ranjit et al., 2002). Yeast count are inhibited at acetic acid levels above $5.6 \mathrm{~g} \mathrm{~L}^{-1}$ of culture (Woolford, 1975) and inoculation with this bacteria has resulted in acetic acid concentrations ranging from 36 to $50 \mathrm{~g} \mathrm{~kg}^{-1}$ in silage $\mathrm{DM}$, equivalent to concentrations above $16 \mathrm{~g} \mathrm{~L}^{-1}$ in the silage liquid phase (Driehuis et al., 1999; Ranjit \& Kung Jr., 2000; Taylor et al., 2002).

UREA, BENZ and SORB treatments had ethanol levels approximately $30 \%$ below ethanol content in the control silage (Table 1). The addition of urea reduced yeast count and ethanol content and greatly increased silage CP content and IVDMD. Dry matter loss in the urea treated silage was higher than in the control and effluent production was the highest among all silages. The alkaline attribute of urea delays $\mathrm{pH}$ drop, which may explain the high silage
DML, despite the observed reduction in yeast count and ethanol production. A prolonged period at $\mathrm{pH}$ above 4 allows plant enzymes, enterobacteria and clostridia to be active, increasing nutrient losses (McDonald et al., 1991; Rotz \& Muck, 1994). Although gas production is the major component of DML, the high amount of effluent may have contributed to increase DML. Assuming an effluent DM concentration of $100 \mathrm{~g} \mathrm{~kg}^{-1}$ (McDonald et al., 1991) the estimated loss due to effluent would be approximately $2.36 \mathrm{~kg} \mathrm{t}^{-1}$ of silage DM or $0.8 \%$ of the initial ensiled dry matter.

Benzoate treated silage reduced ethanol production without significantly affecting yeast count, IVDMD, NDF content and DML as compared to control.; effluent production was greater than in control silage. Sorbate treated silage reduced ethanol concentration whereas increased DML as compared to control. Yeast count, effluent production and IVDMD were unafftected as compared to control. Pedroso (2003) used the same additives and doses and did not detect reduction in ethanol but showed an improvement in IVDMD and reduction in DML, in sodium benzoate and potassium sorbate treated sugarcane silages, respectively. Higher effluent production was also detected by this author in benzoate treated sugarcane silage.

Experimental silages erobic stability and deterioration intensity are observed in Figure 1. Control silage was stable for 48 hours. Silages treated with sodium benzoate and L. buchneri were more stable $(p<0.05)$ than control silage; deterioration started initiating 72 and 78 hours after air exposure, respectively.

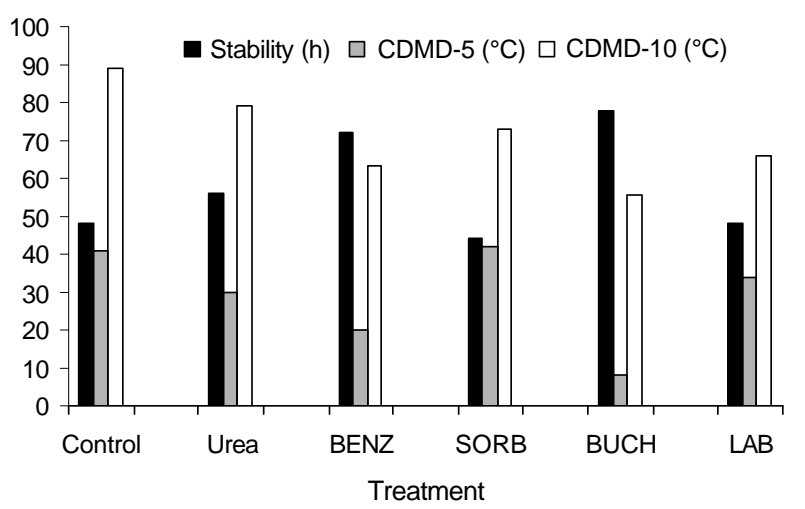

Figure 1 - Aerobic stability ${ }^{(1)}$ and deterioration parameters ${ }^{(2)}$ of sugarcane silages with no additive (control) and treated with: urea - UREA $\left(5 \mathrm{~g} \mathrm{~kg}^{-1}\right)$; sodium benzoate - BENZ $\left(1 \mathrm{~g} \mathrm{~kg}^{-1}\right)$; potassium sorbate - SORB $\left(0.3 \mathrm{~g} \mathrm{~kg}^{-1}\right)$; Lactobacillus plantarum - LAB $\left(1 \times 10^{6} \mathrm{cfu} \mathrm{g}^{-1}\right)$; Lactobacillus buchneri - BUCH $\left(3.64 \times 10^{5} \mathrm{cfu} \mathrm{g}^{-1}\right)$.

\footnotetext{
${ }^{(1)}$ Stability: number of hours for silage to reach $2^{\circ} \mathrm{C}$ above room temperature; ${ }^{(2)} \mathrm{CDMD}-5$ and CDMD-10: cumulative daily average difference between silage and room temperature $\left({ }^{\circ} \mathrm{C}\right)$, after five and ten days of air exposure, respectively.
} 
CDMD-5 and CDMD-10, were also lower $(p<0.05)$ as compared to control, indicating that even after deterioration started microbial activity was less intense. Stability of silages treated with urea, potassium sorbate and L. plantarum was not different than control $(p>0.05)$. Urea treated silage showed a lower CDMD-5 $(p<0.05)$ as compared to control silage, indicating that this additive reduced deterioration during the first five days after air exposure but was ineffective afterwards. Lactobacillus plantarum reduced CDMD-10 ( $p<0.05)$ but CDMD-5 was similar $(p>0.05)$ to control, indicating that silage substrates were intensively consumed during the first five days of air exposure, resulting in lower microbial activity and lower temperatures afterwards. Lactate utilizing yeasts are primarily responsible for silage deterioration upon air exposure (McDonald et al., 1991) and inoculants containing homolactic bacteria are frequently ineffective in improving aerobic stability (Ranjit \& Kung Jr., 2000). Potassiumn sorbate had no marked effect on silage aerobic stability or heat accumulations compared to control.

The improvement in aerobic stability observed in L. Buchneri treated silage (Figure 1) agrees with results observed with corn silage (Driehuis et al., 1999; Ranjit \& Kung Jr., 2000; Taylor et al., 2002), although Junqueira (2006) didn't show any stability improvement in sugarcane silage treated with this same inoculant. The conversion of lactic acid to acetic acid by $L$. buchneri and the fungicide effect of acetic acid are probably the major reasons for stability improvement. Aerobic lactate utilizer yeasts are considered one of the most important deteriorating organisms when silages are exposed to oxygen (Woolford, 1990).

\section{CONCLUSIONS}

Additives may reduce ethanol production and losses and improve digestibility and aerobic stability in sugarcane silages. Sodium benzoate and L. buchneri stand as the most promising additives due to their ability to improve both fermentation pattern and aerobic stability. Caution must be taken when suggesting the use of inoculants for sugarcane silage. Bacteria species which normally improve conservation of traditional crops (corn and sorghum), like L. plantarum, have been shown to be deleterious to fermentation and conservation of sugarcane silages.

\section{ACKNOWLEDGEMENTS}

To FAPESP for supporting the project and to EMBRAPA for the doctorate fellowship granted to the first author.

\section{REFERENCES}

ALLI, I.; BAKER, B.E.; GARCIA, G. Studies on the fermentation of chopped sugarcane. Animal Feed Science and Technology, v.7, p.411-417, 1982

ALLI, I.; FAIRBAIRN, R.; BAKER, B.E. The effects of ammonia on the fermentation of chopped sugarcane. Animal Feed Science and Technology, v.9, p.291-299, 1983.

ANDRADE, J.B.; JUNIOR, E.F.; POSSENTI, R.A.; OTSUK, I.P.; ZIMBACK, L.; LANDELL, M.G.A. Produção e composição de cultivares de cana-de-açúcar. In: REUNIÃO DA SOCIEDADE BRASILEIRA DE ZOOTECNIA, 39., Recife, 2002. Anais. Recife: SBZ, 2002. CD ROM

ASSOCIATION OF OFFICIAL ANALYTICAL CHEMISTS. Official methods of analysis. 15 ed. Arlington: AOAC, 1990. $1117 \mathrm{p}$.

BERNARDES, T.F.; SILVEIRA, R.N.; COAN, R.M.; REIS, R.A.; MOREIRA, A.L.; ITURRINO, R.P.S. Características fermentativas e presença de levedura na cana-de-açúcar crua ou queimada ensilada com aditivo. In: REUNIÃO DA SOCIEDADE BRASILEIRA DE ZOOTECNIA, 39., Recife, 2002. Anais. Recife: SBZ, 2002. CD-ROM

BERZAGHI, P.; COZZI, G.; ANDRIGHETTO, I. The use of near infrared analysis for in situ studies. Journal of Dairy Science. v.80, p.3263-3270, 1997.

BOIN, C.; TEDESCHI, L.O. Cana-de-açúcar na alimentação de gado de corte. In: SIMPÓSIO SOBRE NUTRIÇÃO DE BOVINOS, 5., Piracicaba, 1993. Anais. Piracicaba: FEALQ, 1993. p.107-126.

DRIEHUIS, F.; ELFERINK, S.J.W.H.O.; SPOELSTRA, S.F Anaerobic lactic acid degradation during ensilage of whole crop maize inoculated with Lactobacillus buchneri inhibits yeast growth and improves aerobic stability. Journal of Applied Microbiology, v.87, p.583-594, 1999.

DRIEHUIS, F.; WIKSELAAR, P.G. The occurrence and prevention of ethanol fermentation in high-dry-matter grass silage. Journal of the Science of Food and Agriculture, v.80, p.711-718, 2000.

DUBOIS, M.; GILLES, K.A.; HAMILTON, J.K.; REBERS, P.A.; SMITH, F. Colorimetric method for determination of sugars and related substances. Analytical Chemistry, v.28, p.350, 1956.

HIGGINBOTHAM, G.E.; MUELLER, S.C.; BOLSEN, K.K.; DEPETERS, E.J. Effects of inoculants containing propionic acid bacteria on fermentation and aerobic stability of corn silage. Journal of Dairy Science, v.81, p.2185-2192, 1998.

JUNQUEIRA, M.C. Aditivos químicos e inoculantes microbianos em silagens de cana-de-açúcar: perdas na conservação, estabilidade aeróbia e desempenho de animais. Piracicaba: USP/ESALQ, 2006. 98p. Dissertação (Mestrado).

KUNG JR., L; ROBINSON, J.R.; RANJIT, N.K.; CHEN, J.H.; GOLD, C.M.; PESEK, J.D. Microbial populations, fermentation endproducts, and aerobic stability of corn silage treated with ammonia or a propionic acid-based preservative. Journal of Dairy Science, v.83, p.1479-1486, 2000.

KURTMAN, C.P.; FELL, J.W. The yeast: A taxonomic study. Amsterdan, Elsevier, 1998. 1055 p.

McDONALD, P.; HENDERSON, A.R.; HERON, S.J.E. The biochemistry of silage. 2 ed. Marlow: Chalcomb, 1991. 340p.

MOON, N.J. Inhibition of the growth of acid tolerant yeasts by acetate, lactate and propionate and their synergistic mixtures. Journal of Applied Bacteriology, v.55, p.453-460, 1983.

PEDROSO, A.F. Aditivos químicos e microbianos no controle de perdas e na qualidade de silagem de cana-de-açúcar (Saccharum officinarum L.). Piracicaba: USP/ESALQ, 2003. 120p. Tese (Doutorado).

PEDROSO, A.F.; NUSSIO, L.G.; PAZIANI, S.F.; LOURES, D.R.S.; IGARASI, M.S.; COELHO, R.M.; PACKER, I.H.; HORII, J.; GOMES, L.H. Fermentation and epiphytic microflora dynamics in sugar cane silage. Scientia Agricola, v.62, p.427432, 2005. 
RANJIT, N.K.; KUNG JR., L. The effect of Lactobacillus buchneri, Lactobacillus plantarum, or a chemical preservative on the fermentation and aerobic stability of corn silage. Journal of Dairy Science, v.83, p.526-535, 2000.

RANJIT, N.K.; TAYLOR, C.C.; KUNG JR., L. Effect of Lactobacillus buchneri 40788 on the fermentation, aerobic stability and nutritive value of maize silage. Grass and Forage Science, v. 57, p. $73-81,2002$.

RODRIGUES, A.A.; CRUZ, G.M.C.; BATISTA, L.A.R.; LANDELL, M,G.A. Qualidade de dezoito variedades de cana-de-açúcar como alimento para bovinos. In: REUNIÃO DA SOCIEDADE BRASILEIRA DE ZOOTECNIA, 38., Piracicaba, 2001. Anais. Piracicaba: SBZ, 2001. p.1111-1112.

ROTZ, C.A.; MUCK, R.E., Changes in forage quality during harvest and storage. In: Forage quality, evaluation and utilization. Madison: ASA/CSSA/SSSA., 1994. p.828-868.

SAS INSTITUTE. SAS/STAT user's guide. Cary: SAS Institute, 1988.

SIQUEIRA, G.R. Cana-de-açúcar (Saccharum officinarum L.) ensilada com aditivos químicos e bacterianos. Jaboticabal: UNESP/FCAV, 2005. 91p. Dissertação (Mestrado).
SOEST, P.J. van; ROBERTSON, J.B. Analysis of forages and fibrous foods. Ithaca: Cornell University, 1985. 202p.

TAYLOR, C.C.; RANJIT, N.J.; MILLS, J.A.; NEYLON, J.M.; KUNG JR, L. The effect of treating whole-plant barley with Lactobacillus buchneri 40788 on silage fermentation, aerobic stability, and nutritive value for dairy cows. Journal of Dairy Science, v.85, p.1793-1800, 2002.

WOOLFORD, M.K. Microbial screening of food preservatives, cold sterilezants and specific antimicrobial agents as potential silage additives. Journal of Science of Food and Agriculture, v.26, p.229-237, 1975.

WOOLFORD, M.K. The detrimental effects of air on silage. Journal of Applied Bacteriology, v.68, p.101-116, 1990.

Received March 13, 2007

Accepted April 01, 2008 